\title{
"INTEGRATION" OF THE DISSEMINATION OF INFORMATION UNDER THE SECURITIES ACT OF 1933 AND THE SECURITIES EXCHANGE ACT OF I934*
}

\author{
Harry Heller $\dagger$
}

One of the interesting historical aspects of legislation regulating the distribution of corporate securities and the trading in such securities by dealers and investors is the frequency with which it is re-examined and reassessed. The swiftness of industrial and economic change in free societies such as the United States and the countries of Western Europe makes reappraisal of the effects of securities legislation a recurring necessity. In England, the Companies Act, which contains the requirement for the use of prospectuses in the sale of securities to the public and prescribes the information to be contained in such prospectuses, has been revised in our own generation in 1929 and $19477^{1}$ Since 1959 it has also been the subject of a study and report by a committee (known as the Jenkins Committee in honor of its chairman, Lord Jenkins) appointed by the Board of Trade. ${ }^{2}$ Our own legislation-the Securities Act of 1933 and the Securities Exchange Act of 1934 -has been reviewed in I940 and I94I (no legislative action was then taken) and in 1954 when substantial amendments were made to the Securities Act of $19333^{3}$ In I96I Congress directed the Commission to make a study of the nation's securities markets and to report the results of its study, including any recommendations which the Commission felt were desirable. The Commission organized a separate staff to conduct the study. The results of such study are now embodied in a four-part Report of Special Study of Securities Markets of the Securities and Exchange Commission."

* This article bears a date of May 15, 1964 . bars.

† A.B. I929, LL.B. I933, Columbia University. Member of the New York and District of Columbia

${ }^{1}$ For a brief history of the amendments to the English Companies Act, see LAwrence C. B. GowER, The Principles of Modern Company Law 39-58 (2d ed. 1957).

${ }^{y}$ Great Britain Board of Trade, Report of the Company Law Committee, Caind. No. I749 (1962) [hereinafter cited as JENKINS REPORT].

${ }^{3}$ For a brief history of the amendments to the Securities Act of 1933 and the Securities Exchange Act of 1934, see Dean, Twenty-five Years of Federal Securities Regulation by the Securities and Exchange Conmission, 59 Colum. L. Rev. 697, 713-47 (1959). See also Securities and Exchange Commission, 7tth Cong., ist Sess., Report on Proposals for Amendaent to the Securities Act of 1933 and the Securities Exchange Act of 1934 (Comm. Print I94I); Hearings Before the House Comm. on Interstate and Forcign Commerce on H.R. 7550 and S. $2846,83 \mathrm{~d}$ Cong., $2 \mathrm{~d}$ Sess. (1954).

The sections of the Securities Act of $1933,4^{8}$ Stat. 74 (1933), as amended, 15 U.S.C. $\$ \$ 77 a-a a$ (1958), as amended, 15 U.S.C. $\$ \$ 77$ b-h (Supp. IV, 1963) [hereinafter cited as Securities Act], and the Securities Exchange Act of 1934,48 Stat. 88I (1934), as amended, 15 U.S.C. $\$ \$ 78 \mathrm{a}$ to hh-l (1958), I5 U.S.C. $\$ \$ 78 \mathrm{c}$-s (Supp. IV, 1963 ) [hereinafter cited as Securities Exchange Act] will be referred to herein as they appear in such acts.

Securities Exchange Act $\$$ I9 (d).

${ }^{5}$ Securities and Exchange Commission, Report of Special Study of Securities Markets, H.R. Doc. No. 95. 88th Cong., Ist Sess. (1963) [hercinafter cited as Special Study]. 
Curiously, both the Jenkins Committee and the Special Study deal extensively with the possibility of coalescing the dissemination of information concerning corporations, their businesses and their securities, to investors, whether in connection with a distribution by the corporation itself (or its controlling stockholders), which would be subject to the prospectus requirements of the Companies Act, or the registration and prospectus requirements of the Securities Act, or in connection with other distributions of, or trading in, already outstanding securities by securities dealers and the investing public. ${ }^{.}$The proposal of the Special Study is to "integrate" and unify disclosures to be made to investors irrespective of the immediate origin of the securities offered to them. ${ }^{7}$ An understanding and a critique of the proposal requires a brief description of the essential regulatory features of the Securities Act and the Securities Exchange Act.

- The Companies Act, 1948, II \& 12 Geo. 6, c. 38 , prescribes the requirements for incorporation in England and requires a prospectus (subject to certain exemptions set forth in the act) to be published to investors in the case of public offerings for cash by a company. The act in its Fourth Schedule scts forth the areas of information to be included in the prospectus. Although the act requires the prospectus to be filed with the Board of Trade, that body does not pre-examine its contents for truth or accuracy. However, as set forth in note 32 infra, the London Stock Exchange makes a critical and searching examination of prospectuses pertaining to securities which it is requested to list.

The Prevention of Fraud (Investments) Act, 1958, 6 \& 7 Eliz. 2, c. 45, requires the licensing by the Board of Trade of all dealers in securities other than members of recognized stock exchanges or associations of dealers in securities or dealers exempted on application by the Board of Trade. The act contains provisions enabling the Board of Trade to prescribe standards of conduct for dealers and requires them to keep records. The Board is also empowered to discipline dealers. Section $\mathrm{I}_{3}$ of this act prohibits the use of written material offering securities for sale (except the Companies Act prospectus) unless such circular is issued by a licensed dealer or a member of a recognized stock exchange or dealers' association. The act also forbids circulars to contain any statements, promises or forccasts which the circulator knows to be misleading, false or deceptive, and also forbids any dishonest concealment of material facts or the reckless making of any statement, promise or forecast which is misleading, false or deceptive.

On the subject of a proposed consolidation of the Companies Act and the Prevention of Fraud (Investments) Act, the Jenkins Report contains the following:

" $23 \mathrm{I}$. It has been suggested to us that the existing provisions relating to issuing and dealing in securities in the Companies Act, 1948, and the Prevention of Fraud (Investments) Act, 1958, might with advantage be consolidated in one act. This might be done by combining with the provisions of the present Companies Act relating to prospectuses and offers for sale the provisions now contained in the Prevention of Fraud Act with respect to the distribution and contents of circulars . . . .

"234. We recommend that: -

".. (b) if practicable, the law should be consolidated by transferring to the Companies Act the provisions relating to the distribution and contents of circulars, and those relating to Unit Trusts, contained in the Prevention of Fraud (Investments) Act . . . ."

It is not clear whether the Jenkins Report recommends a mere consolidation of the laws or would amend the laws to require standards of disclosure in circulars used in cases where a prospectus is not required under the Companies Act. The Jenkins Committec left this entire matter in the hands of a committee (already in existence) of persons concerned with securities legislation.

${ }^{7}$ Professor Louis Loss of the Harvard Law School has advocated the integration and combination of all of the federal securities laws. In testimony before a congressional committee, he said:

"I think, if I may say so, that in a few years, when the section II program under the Holding Company Act, the integration and simplification program, has been quite completed, it might be a good time to have a general look at all these statutes, with a view to integrating them into a simple code that would make life simpler for everybody.

"And my second point is that, when that day comes, any such gencral re-examination should not be a one-way street. It should seek to eliminate both unnecessary overlapping and unnecessary and illogical gaps." Hearings Before the House Comm. on Interstate and Foreign Commerce on H.R. 7550 and S. $2846,83 \mathrm{~d}$ Cong., $2 \mathrm{~d}$ Sess. 107 (1954). 


\section{The Mechanics of "Integratron"}

The Securities Act regulates the public distribution of corporate securities offered either by a business organization itself or by its controlling persons. The regulation encompasses the filing with the Securities and Exchange Commission (SEC) anterior to any such offering of a "registration statement," which contains material information concerning the company and its affairs prescribed by the Securities Act itself and the rules and regulations and forms of registration devised by the Commission pursuant to the authority of the act. ${ }^{8}$ The Securities Act also requires that at some stage in the process of offering and selling the security, the purchaser receive a prospectus setting forth the material in the registration statement prescribed by the Commission. ${ }^{9}$ The latest point at which the purchaser can receive the prospectus is with the delivery of the security to him after sale. However, since -any written confirmation of the sale of the security is a prospectus as defined in the act ${ }^{10}$ and since such confirmation cannot be mailed unless accompanied or preceded by the prospectus required by the statute, ${ }^{11}$ in practice the purchaser receives the prospectus with the confirmation of his purchase.

Between the date of the filing of the registration statement and the effective date of the statement under the Securities Act, a "waiting period" of twenty days is required unless the Commission shall shorten such period on application by the company. ${ }^{12}$ During the waiting period written offers of the securities covered by the registration statement may be made only by a "preliminary prospectus" or a "summary prospectus." ${ }^{13}$ The preliminary prospectus contains substantially all the information required in the prospectus filed with the registration statement, other than the offering price, underwriting commission, and incidents of the security offered which are dependent upon the offering price, such as the basis of conversion in the case of a convertible security. These omissions are permitted because price and underwriting spread are usually determined by the company and the underwriters immediately prior to the effective date of the registration statement. The Commission, in order to promote the dissemination of material information during the waiting period, conditions its granting of requests to shorten the statutory waiting period (a procedure known as "acceleration") upon an adequate distribution of preliminary prospectuses to dealers who are to become members of the dealer selling group..$^{14}$

\footnotetext{
${ }^{8}$ Sccurities Act $\$ 55,7$.

${ }^{\circ}$ Securities Act $\$ \$ 5$, Io.

${ }^{10}$ Securities Act $\$ 2$ (10).

11 Sccurities Act $\$ 5$ (b)(I).

${ }^{12}$ Securities Act $\$ 8(a)$.

${ }^{23}$ Securities Act $\S 5(\mathrm{~b})(\mathrm{I})$, Rules 433 and $434 \mathrm{~A}$ of the General Rules and Regulations under the Securities Act of 1933, I7 C.F.R. $\$ 230.433, .434$ (Cum. Supp. I963).

${ }^{14}$ Rule 460 of the General Rules and Regulations under the Securities Act of 1933 , I7 C.F.R. $\$ 230.460$ (Cum. Supp. r963).
} 
Authority to permit the use of a summary prospectus was provided for in the 1954 amendments to the Securities Act. ${ }^{15}$ The purpose of the summary prospectus is to permit circulation to investors of an inexpensive summary of material categories of information selected by the Commission and deemed sufficient to enable investors to determine whether they wish to obtain the preliminary or effective prospectus. The summary prospectus is not subject to the civil liabilities of section Ir of the Securities Act, although it is subject to the liabilities created by sections $12(2)$ and 17(a) of that act. Summary prospectuses may be used only by companies which are required to file periodic reports with the Commission pursuant to either section 13 or section 15 (d) of the Securities Exchange Act or by companies which have net assets of $\$ 5,000,000$ or more, have filed profit and loss or income statements with the registration statement and have been engaged in substantially the same business for the three preceding years, have had a net income of at least a half million dollars and, except in certain cases, have distributed to shareholders and made generally available an annual report in each of such three years. ${ }^{10}$ Summary prospectuses need contain only a summary of the facts stated in the registration statement concerning the following categories of information: the offering price and underwriting discounts, the names of the managing underwriters and the general nature of the underwriting commitment, the proposed method of distribution of the securities, the intended use of the proceeds of the offering, a statement of the nature of offerings being made other than for cash, the company's capitalization, a summary of its earnings in the detail required in the full prospectus for the preceding five years, the date and form of organization of the company, state of its organization if such organization occurred within the preceding five years, a brief statement of the general character of the business done by the company and intended to be done, a statement of proposed and past transactions with the promoters of the company, if any, a statement of any impending material litigation against the company, a description of the securities being registered, and a statement as to any outstanding options to purchase securities of the class being registered. A balance sheet and a surplus analysis is not required and the use of condensations of such financial statements is expressiy forbidden. ${ }^{17}$

Historically, despite its short form character, the summary prospectus has not been greatly used. Possible reasons are: (I) the summary prospectus must be followed by the actual prospectus; (2) the possibility of civil liability under section I2(2) of the Securities Act inherent in attempts at condensation; and (3) the belief

${ }^{26}$ Securities Act $\S$ ro(b). Summary prospectuses must be in the form and content prescribed by the rules of the Commission and must be included in the registration statement. They cannot be uscd for five days after filing, a period of time during which the Commission staff examines and checks the summary prospectuses against the registration statement and other information which it possesses concerning the company.

${ }^{10}$ Rule $434 \mathrm{~A}$ of the General Rules and Regulations under the Securities Act of 1933, 17 C.F.R. $\$ 230.434$ A (Cum. Supp. 1963).

${ }_{17}$ Form S-I, Instructions as to Summary Prospectuses. Form S-I is the Commission's basic form of registration under the Securities Act. 
of many elements in the industry that such prospectuses do not sufficiently apprise investors of the facts concerning the security to enable them to make a meaningful analysis of the merits of the security. The probability is that the disuse of the summary prospectus may be traced to all of these reasons in combination.

In addition to the registration and prospectus requirements, the Securities Act also outlaws fraud in the sale of registered or unregistered sale of securities, whether the sale is made by the issuer of the securities, its controlling persons, or others. ${ }^{18}$ A civil action is also provided against those who sell securities, whether registered or unregistered, by misleading statements or omissions of material facts required to make statements made not misleading under the circumstances. ${ }^{19}$

The Securities Exchange Act regulates the trading in, and distribution of, securities by brokers and dealers. The act regulates listing and trading of securities on national securities exchanges by (I) requiring such exchanges to be registered, ${ }^{20}$ and (2) requiring companies whose securities are listed or are to be listed upon such exchange to file a registration statement containing prescribed information concerning the company and its business and to keep such information current by annual and interim reports. ${ }^{21}$ The act also requires the registration of brokers and dealers ${ }^{22}$ and authorizes the Commission to prescribe rules and regulations to eliminate manipulative, deceptive and fraudulent practices by broker-dealers in over-the-counter securities. ${ }^{23}$

However, except for companies which have registered securities under the Securities Act in certain prescribed amounts, ${ }^{24}$ the Securities Exchange Act does not require filing of information with the Commission concerning companies the securities of which are traded only over-the-counter. Since state laws do not ordinarily require the dissemination of information concerning their domiciled corporations to the public, a substantial gap has existed since the inception of the Securities Exchange Act between public information available concerning listed securities and companies registered under the Securities Act and securities of other publicly-held companies which are traded over-the-counter. This anomalous regulatory gap has confronted the Commission for years and it has persistently sought legislation to close it. To accomplish this purpose the Commission has recently introduced legislation which has passed the Senate and is now pending in the House of Representatives. ${ }^{25}$

${ }^{18}$ Securities Act $\$$ I 7 (a) (I), I7(a)(3).

${ }^{20}$ Securities Act $\$$ I2(2), I7(a) (2).

${ }^{20}$ Securities Exchange Act $\S 6$.

${ }^{2 x}$ Securities Exchange Act $\$ 12$.

${ }^{23}$ Securities Exchange Act $\$ 15(a)$.

${ }^{23}$ Securities Exchange Act $\$ \S$ Io(b); $x_{5}(c)$.

a' Securities Exchange Act $\$ 15$ (d).

${ }^{25}$ S. I642 passed on July 30, I963. Iog Cong. REc. 12962 (1963). H.R. 6973, 88th Cong., 2d Sess. (1964), the House version of S. I 642 , was reported to the House Committee on Interstate and Foreign Commerce by its subcommittee on March 26,1964 .

Chapter IX of the Special Study deals extensively with the so-called regulatory gap in reporting and marshals the empirical evidence for legislation requiring the filing of reports by publicly held companies the securities of which are traded only over the counter. The securities of virtually all stock insurance 
On the assumption that this legislation passes and information concerning such other publicly-held over-the-counter companies is equated to that available for listed companies and those companies which meet the requirements of section $15(\mathrm{~d})$ of the Securities Exchange Act, the Special Study suggests that attention be directed toward a unified disclosure and dissemination of filed information irrespective of the type or character of the distribution of securities or their registered status under the Securities Act.

The Securities Act and the Securities Exchange Act are mutually exclusive. Registration under the Securities Act of 1933 does not constitute registration under the Securities Exchange Act of 1934. Nor does listing on a national securities exchange constitute registration under the Securities Act of 1933 . The latter act applies to listed or unlisted securities alike and comes into operation whenever a company or its controlling persons proposes to offer securities of the company to the public.

Before setting forth the specific proposals of the Special Study, it should be pointed out that the Commission has already achieved a degree of integration with respect to the filing requirements contained in each act. A registration statement under the Securities Act can become the basic registration statement under the Securities Exchange Act. ${ }^{28}$ Similarly, financial statements and other information required by the Securities Act which are already on file pursuant to the registration requirements of the Securities Exchange Act or other acts administered by the Commission may be incorporated by reference in a registration statement under the Securities Act. $^{27}$ The enforcement of the fraud provisions of both acts and the discipline of broker-dealers have been administratively integrated by the Commission in one of its divisions, the Division of Trading and Markets.

It is, however, the movement of the information filed by reporting issuers with the Commission to the public and the internal correlation necessary for its accomplishment which the Special Study seeks to unify. Its recommendations are as follows:

On the assumption of and in harmony with the carrying out of recommendations in chapter IX for extending and strengthening Exchange Act reporting requirements and wider dissemination and use of filed reports, the Commission, in consultation with in-

companies and banks are traded only over the counter. S. 1642 would extend the reporting and proxy solicitation requirements of the Securities Exchange Act initially to companies having $\$ 1,000,000$ in assets and 750 or more stockholders of record. After two years the stockholder test would be reduced to 500. It is estimated that under the 750 shareholder standards approximatcly 3,100 companies would be covered, of which 400 would be banks subject to appropriate federal banking regulatory agencics. About 1,500 of the remaining 2,700 companies are already required to file reports with the Commission under $\$ I_{5}(\mathrm{~d})$ of the Securities Exchange Act, because they have previously filed registration statements involving offers of securities at an aggregate offering price in excess of $\$ 2,000,000$. Under the 500 stockholder standard the estimated figures are 3,900 companies covered, of which 600 are banks and 1,700 are companies already required to file reports.

${ }_{20}$ Rule I2b-35 of the General Rules and Regulations under the Securities Exchange Act of 1934, 17 C.F.R. \$240.12b-35 (Cum. Supp. 1963).

${ }^{27}$ Rule 4 II of the General Rules and Regulations under Securities Act of 1933, I7 C.F.R. 5230.411 (Cum. Supp. I963). However, financial statements required to be included in the prospectus cannot be incorporated in such prospectus by reference. 
dustry representatives, should seek to develop a program for closer integration of disclosure requirements of the Securities Act and the Exchange Act, a possible outline of which is as follows:

I. A registered public offering of securities of any issuer (with the exceptions as may be provided under rules of the Commission) already subject to the continuous reporting requirements of sections I3, I4 and I6 of the Exchange Act, by reason of having a class of stock registered on a national securities exchange or a class of "OTC listed" stock (see ch. IX), should be permitted under a special "short-form" registration statement and prospectus. Such short-run registration statement or prospectus should be required to contain data concerning price and spread, and underwriting arrangements; if a primary offering, the proposed use of proceeds, or if a secondary, the reasons for selling; capitalization; summary of earnings; recent developments in business and other material occurrences not previously reported; financial statements, and a specific reference to previously filed material fulfilling other requirements of the appropriate registration form, with a representation and consent that such material shall be deemed part of the present registration statement and prospectus for all purposes of sections II and I2 of the Securities Act.

2. To the extent, if any, that present reporting requirements (forms $8-\mathrm{K}, 9-\mathrm{K}$ and Io-K) or proxy soliciting requirements may be inadequate to assure an adequate reservoir of reliable information on a current basis, these inadequacies should be appropriately corrected entirely apart from the present recommendations. Also, to the extent practicable, examining procedures now followed in connection with prospectuses and proxy statements should be made applicable to annual and other reports.

3. The waiting period between filing and effective date should be kept to a minimum for short-form filings. The 40-day period during which all dealers are required to deliver prospectuses should be eliminated in the case of short-form filings, without limiting the obligation of any dealer in respect of securities constituting some or all of an unsold allotment to or subscription by such dealer as a participant in the distribution. ${ }^{28}$

5. The importance of disclosure for the protection of investors has long been recognized in securities regulation, and it is of particular value in connection with selling practices. The present mandatory, officially filed disclosures by issuers (reports and proxy statements), extended and improved as recommended in chapter IX, should have wider and more prominent use in selling activities, and the obligations of broker-dealers in this regard should be appropriately defined by the self-regulatory agencies and the Commission. These obligations might include such matters as: actually consulting available officially filed data prior to recommending or selling specific securities; furnishing copies to customers in appropriate cases; and advising customers whether officially filed information is available with respect to any security recommended for purchase. ${ }^{29}$ ...

8. If disclosure of information is fundamental in federal securities regulation, the widest possible dissemination and use of filed information will obviously best serve the purposes of disclosure. In light of modern techniques for duplicating and communicating the printed word, it would seem that dissemination and not mere filing should be required in many instances. For example, just as there are now unofficial services that regularly distribute summaries of data concerning individual securities, it would seem feasible to require officially filed information to be presented in form for inexpensive duplication and distribution. It would also seem possible to require that copies be filed in appropriate Commission or NASD offices and/or that broker-dealers making markets

${ }^{28}$ Special Study, pt. I, at 594-95.

${ }^{29}$ Special Study, pt. I, at 329. 
or recommending purchases have copies on file or actually distribute them to customers in stated circumstances. The technical and economic feasibility of such measures and the advances in investor protection that they would make possible should receive immediate and continuing study by the Commission and the self-regulatory agencies. ${ }^{30}$

An assessment of the merits and feasibility of these proposals from the viewpoint of their aid to investors-the only real criterion for evaluation-will require an analysis of their impact upon established practices and administrative procedures and existing standards of disclosure in the public distribution of securities. The exploration of the effect of "integration" upon these matters is essentially the subject of this article.

The Special Study is relatively precise in its recommendations as to the issuers which may utilize a short form registration statement or prospectus and the content of such registration statement or prospectus. It is less clear-in fact, quite vagueas to the circumstances and conditions under which securities dealers and others shall be obligated actually to place in the hands of investors information concerning a non-registered issue which is the subject of a distribution or a recommendation to purchase made to investors. Nor does the Special Study make clear precisely what information is to be furnished to investors in cases of non-registered issues.

The Special Study's recommendation for permitting the use of a short-form prospectus and registration statement by companies which are subject to the reporting requirements of the Securities Exchange Act presumably will have the approval of the New York Stock Exchange (NYSE) which has for some time been intrigued with the possibility of the increased listing upon its board which might occur if listed companies were not subject to the full force of the registration requirement of the Securities Act. During the last ten years the Exchange has consistently sought and advocated a complete exemption from the Securities Act registration and prospectus requirements for offerings made by companies listed on national securities exchanges for three years or more. Support for the Exchange proposal can perhaps be derived from that provision of the British Companies Act which exempts from the prospectus requirements offerings by a company with securities "uniform in all respects" with its securities already listed on English stock exchanges. ${ }^{31}$ However, the Companies Act exemption is justified by the requirement of the London Stock Exchange (upon which the great majority of publicly owned British companies are listed and upon which the great majority of such companies seek listing) that, as a condition to the listing of new issues of already listed companies, the company prepare a prospectus in some respects more extensive than that required by the Companies Act or that proposed by the Special Study. ${ }^{32}$ Moreover, the London Stock Exchange

${ }^{30}$ Special Study, pt. 3 , at 64 .

${ }^{31}$ Companies Act, r948, II \& 12 Geo. 6, c. $38, \$ 38(5)$.

${ }^{33}$ See Jenkins Report I 221. See also Appendix 34, Schedule II, Part B (Requirements for Quotation), Rule 159 (2) of the Rules and Regulations of the London Stock Exchange (1962). The Exchange rules require, among other things, the name of the company, a statement by the directors "collectivcly and individually" if the prospectus is to be circulated among statistical scrvices that they "accept full 
in many respects performs the functions of examination, scrutiny and correction of the required information contained in the prospectus which in our country are performed by a public body, that is, the Commission. ${ }^{33}$

Notwithstanding the fact that the quest for a short-form prospectus and registration statement is attractive, attempts in the past by the Commission to provide for condensed information and condensed financial statements have not been enthusiastically greeted by the securities industry other than the NYSE. The summary

responsibility for the accuracy of the information given and confirm having made all reasonable inquiries that to the best of their knowledge and belief, there are no other facts the omission of which would make any statement in the prospectus misleading"; a description of the security offered and for which quotation is sought; a statement as to the financial and trading prospects of the company, together with any material information relevant thereto; a statement by the directors that in their opinion, working capital is sufficient or, if not, how additional working capital will be provided; financial statements of any subsidiaries acquired since the company's last audited report; a statement since the date of the last audited report as to all securities which have been issued or are proposed to be issued, other than for cash, and the consideration received or to be received for such shares; information as to options on the company's securities; full particulars of the interest of directors or any of them in any property acquired by the company or its subsidiaries since the date of the last audited report; and a description of all material contracts not made in the ordinary course of business. In addition, the prospectus must designate a place within the City of London where for not less than 14 days the audited accounts of the company for each of the two financial years immediately preceding the publication of the prospectus, together with all notes, certificates or information required by the Companies Act, will be available for inspection by investors.

Although the rules of the London Stock Exchange defining the content of prospectuses used in connection with the issue of securities of a class already listed do not require a description of the business of the issuing company, the requirement for a statement of the "financial and trading prospects of the company" appear in many cases to make a description of the risks inherent in the company's business necessary. As is pointed out on p. 773, at note 67 infra, companies filing registration statements on Form S- 9 have included detailed descriptions of their business even though there is no specific requirement in the form for such a description.

${ }^{33}$ In England, as a practical matter, securities offered to the public must be listed on the London Stock Exchange if they are to have any public acceptance. As a condition of listing, the prospectus must be presented to the Exchange for its criticism and comments in advance of public sale of the securities. The Share and Loan Department of the Exchange makes a careful and intensive examination of the accuracy of the statements in the prospectus and of the background and character of the managerial personnel of the company. Sce Althaus, Viewpoint of the Stock Exchange, in Tre CoMpany Prospectus 7 (Gee \& Co., r953). See also Jenkins Report I 252(q) which contains a recommendation that the Board of Trade scrutinize for misleading statements prospectuses relating to securities for which listing on the London Stock Exchange is not contemplated. Presently the Board of Trade does not investigate the accuracy of prospectuses filed with it pursuant to the requirements of the Companies Act. Sec also Gower, op. cit. supra note $x$, at $273-89$.

The financial bar will find a nostalgic interest in the requirement of the London Stock Exchange as to the filings of amendments to the prospectus. The Exchange's rules provide that where any material amendment is made, copies shall be submitted to the Share and Loan Department for approval and such copies "shall be marked in red to indicate amendments to comply with points raised by the Department and in blue or black to indicate other amendments." The point of view of an English solicitor in respect of the Stock Exchange's scrutiny of prospectuses also has an interesting analogy for the American bar. In Brown, The Lawyer's Approach, in The Company Prospectus I6, 27 (1953), the following appears: "Also ... the necessity to submit the draft [of the prospectus] to the Share and Loan Department of the Stock Exchange for comment can be most useful. I know that on occasions the comments made by the officials of that department appear, to those familiar with the details of the matter, to be futile and irritating. They do, however, and by no means infrequently, notice - points which others have overlooked, and I personally would regret any change in the procedure in this respect. But I suppose that, following the advice I give to my clients on prospectuses, I ought to "come clean' and disclose to you that I am interested, since. I have the privilege of acting, as one of the legal advisers to the Stock Exchange." 
prospectus is illustrative of this fact. Investment bankers have feared that condensa. tion might enhance the possibility of liability under the civil liabilities sections of the Securities Act and the Securities Exchange Act. ${ }^{34}$ In addition, the mere existence of information in the files of the Commission does not in itself justify a cutting down of information required to reach the investor. The essence of the purpose of the Securities Act is to place in the hands of an investor, in the crystallized form of a prospectus, all of the essential information required for an intelligent analysis of value so that he need not be required to go elsewhere to form a judgment as to the merits of the security. What is basically necessary is a determination of the information which is essential to judgment formation and a system for placing such information in a compact package in the hands of an investor prior to the time he makes a decision to purchase or sell a security.

Later sections of this article will discuss what information is essential to the making of this decision. There are, however, certain important considerations in the mechanics of preparing and filing information and registration statements with the Commission and the processing of such filings by the Commission staff which have an important bearing on the feasibility of "integration" and which need discussion here.

The Securities Act provides for a registration statement and prospectus which is basically current as of the effective date of the offering. In the preparation of a registration statement and prospectus there is applied the knowledge of counscl, independent public accountants for the issuer and, usually, counsel for the underwriter and the underwriters themselves. Finally, there is a careful examination of the end product of these individuals by the staff of the Commission. The result, generally speaking, is a carefully worked out compendium of information which has been preceded by a carefully prepared inquiry into the business of the company, its divisions, and their relative contributions to sales, their relative risks and competition. In addition, known trends in the backlogs of business and receipts of new orders by the issuer are carefully explored.

In contrast, filings under the Securities Exchange Act represent the product of the company and its counsel and its independent accountants only. The advice and critical scrutiny of an investment banking house which itself may incur civil liabilities for errors and omissions is absent. And, although the original form of registration (Form ro) is carefully scrutinized by the Commission's staff, the annual and interim reports required by the act normally receive only secondary attention by the staff which as a matter of practice gives precedence to Securities Act registration statements in its examination procedure. The review of annual and interim reports is particularly superficial during a time when, as in the roughly two-year period ending May $3^{\mathrm{r}}$, 1962 the volume of registration statements filed under the

\footnotetext{
${ }^{34}$ See the testimony of Professor Loss in Hearings Before the Hortse Comm. on Interstate and Foreign Commerce on H.R. 7550 and S. $2846,83 \mathrm{~d}$ Cong., $2 \mathrm{~d}$ Sess. 105-06 (1954).
} 
Securities Act was extraordinarily heavy. Moreover, the information required by the annual report (Form ro-K) and the interim reports (Forms $8-\mathrm{K}$ and $9-\mathrm{K}$ ) is not current. The annual report need not be filed with the Commission until r2o days after the close of the fiscal period for which the information is filed. The interim reports are required to be filed on the occurrence of certain events and then only within ten days of the close of the month in which the event occurs. The semiannual report of earnings (Form $g-K$ ) is not required to be filed before forty-five days after the close of the semiannual accounting period.

Unlike Securities Act prospectuses, which are relatively compact, the filings under the Securities Exchange Act are characterized by their bulk and lack of periodic synthesis. Annual reports are followed by interim reports, which are followed by annual reports. Interim reports disclose acquisitions and dispositions of properties, issuances and reductions in outstanding capital, and other matters. Although the annual report requires a discussion of changes in the business of a company during the preceding annual fiscal period, this requirement is frequently honored more in the breach than in the observance. In short, to obtain the current situation of a company, a very careful analysis, synthesis, and correlation of the filed information may often be required since it is often difficult to determine whether information once filed is any longer relevant.

In addition, information which investors find important to the making of intelligent judgments about a security is not required to be filed under the provisions of the Securities Exchange Act. The Securities Exchange Act does not require disclosure of material contracts of the issuer-whether or not made in the ordinary course of its business. Legislation proposed by the Commission, however, and now pending before Congress, would correct this deficiency. ${ }^{35}$ The Commission also has not exercised its authority under the Securities Exchange Act to require earnings reports in addition to those contained in the annual and semiannual reports. In this respect, the Commission lags behind the NYSE and other exchanges which require for the great bulk of their listed companies the publication of quarterly statements of earnings. ${ }^{36}$ Material information such as known trends in backlogs of orders and the current rate of receipt of new orders are not required to be furnished. Transactions between the company and its subsidiaries with insiders are required to be reported only in the annual report or in a proxy statement which presently is required only if a solicitation of proxies occurs. ${ }^{37}$

The Special Study is quite right in its recommendation that irrespective of the

st Sce note 25 supra.

3a Sce N.Y. Stock Exchange Company Manual A-69.

${ }^{87}$ The Commission's proposed legislation to bring certain publicly-held over-the-counter companies within the reporting and proxy solicitation requirements of the Securities Exchange Act would require the furnishing annually to shareholders of information equivalent to that contained in a proxy statement used in connection with the annual mecting, even if a solicitation of proxies is not in fact made. See S. ReP. No. 379, 88th Cong., Ist Sess. 24 (1963). The NYSE for the past several years has imposed the same requirement upon its listed companies. 
problem of integration, the Commission should consider the development of requirements for more current information and for more current processing by the staff of such information. ${ }^{38}$ Steps in this direction might include requirements that annually a five-year summary of earnings be presented. A further step might also be. a rule that annually, not a description of changes in the business during the year, but a restatement of its business, be made in the form required by the standards of the Securities Act. Such restatements would seem essential if broker-dealers and investment bankers making distributions not required to be registered under the Securities Act are to be compelled to disseminate information concerning earnings and the current business of the company. The financial bar is well aware of the sometimes radical changes which are required in previously reported earnings as a result of the effect of later events upon such earnings.

The Special Study conceives of its proposals for short-form registration statements and prospectuses for companies reporting under the Securities Exchange Act as a time-saving device. The Special Study's concept of short-form registration, however, does not really contemplate a short-form statement in fact. What it contemplates is a registration statement divided between information filed for the purposes of the Securities Act and information previously filed under the Securities Exchange Act and incorporated by reference into such registration statement. Mechanically, therefore, it is difficult to see in what respect processing time by the staff of the Division of Corporation Finance of the so-called short-form registration statement can be shortened. In practice, the staff will examine the two filings simultaneously. Moreover, the financial bar itself may find that the preparation of registration statements and prospectuses in their traditional form is preferable to the filing of the extensive amendments which may be necessary to keep current the reports filed under the Securities Exchange Act. A proper respect for possible liabilities under the civil liabilities sections of the various acts also may dictate such a course. The Special Study is most unclear as to the persons in the chain of distribution upon whom will fall the burden to make the disclosures of material information which do not appear in the short-form prospectus. Thus, it may be illusory to postulate a shorter waiting period for short form registration statements as a necessary consequence of integration.

Another reason for incorporating all material and information into the prospectus

${ }^{38}$ Form 8-K, the present form for filing interim information under the Securitics Exchange Act, requires the information to be filed within ten days after the close of the month in which the cvent required to be reported occurs. Moreover, the events which must be reported are limited to those specified in the first eleven items of the form. The company may, at its option, report any other information which it considers material. Consideration should be given to a requirement that a Form 8-K report be made promptly after the release by the reporting company directly or by its representatives, such as public relations counsel, indirectly, of information concerning the business of the company other than routine changes in its management. Thus, press releases would become subject to the civil and criminal liabilities of the Securities Exchange Act. The Special Study's proposed legislation to make intentional or reckless dissemination of misleading statements in press releases a criminal offense vould thus become unnecessary. See Special Study, pt. 3, at 99-roz. 
results from the imposition of liability by section $\mathrm{I} 2$ of the Securities Act upon any person who offers or sells a security by means of a prospectus containing any material misstatements or omissions. It is far from clear that the requirements of that section are met by a prospectus which merely incorporates material facts by referring to documents or reports filed with the Commission. ${ }^{39}$ For example, the Special Study's proposed short-form prospectus need not contain any material describing the remuneration of the company's officers and directors or their transactions with the company. However, in many cases such information may be material. As a consequence, attorneys for issuers, underwriters, and dealers may not feel that their clients are sufficiently protected unless such information is included in the prospectus or otherwise physically placed before the investor.

As has been indicated, the Special Study Report suggests the need for the dissemination of information to investors requested to purchase securities in the case of distributions not subject to the registration requirements of the Securities Act. In a subsequent section of this article, an attempt will be made to describe the situations in which such disclosure is desirable and important. At this juncture, however, it is necessary to emphasize the fact that in the case of unregistered offerings, the already described problems which exist in the case of registered offerings are much more acute. These problems form the background for industry opposition to the idea that material information must be physically given to investors offered securities in public distributions not subject to the registration requirements of the Securities Act. The industry argues that the information required in annual and interim reports under the Securities Exchange Act are "of interest to expert technicians and analysts and certainly not to the ordinary investor." ${ }^{38 a}$ It argues further that obtaining and conveying the information to investors will be costly and burdensome and beyond the economic capacities of the ordinary broker-dealer. It also asserts that the industry should be its own best judge as to what information is needed for investors and the sources from which it may be obtained. ${ }^{40}$

Although the industry's criticism reflects a fear that the Special Study intends to impose duties on broker-dealers to collect and disseminate information in a far larger number of cases than a fair reading of the Special Study would indicate, a valid concern does exist in those cases where the duty would be imposed. This concern would be intensified if the Special Study's suggestions for a substantial overhauling and improvement in reporting requirements under the Securities

\footnotetext{
${ }^{30}$ There would be no problem under $\S \mathrm{Ir}$ of the Securities Act, since liability under that section is based salely on information stated or omitted from the registration statement. Information has traditionally been permitted to be included in a registration statement by incorporating it by reference.

${ }^{\text {gor }}$ Miemoranduas on Seliting Practices of the American Securities Industry-A Proposat of Policy and an Analysis of Related Recommendations in the Securities and Exchange Commission Study by an Ad Hoc Commtrtee of the Investment Bankers Association of Ameruca 44 (Dec. 2, 1963).

${ }^{\circ} \mathrm{lbid}$.
} 
Exchange Act along the lines which have been previously suggested is not accomplished.

Reproduction of the actual filed reports in the order in which they have occurred, for example, for the five preceding fiscal years, would indeed be cumbersome and difficult of analysis by an ordinary investor. Concise summaries of earnings and descriptions of a company's business are essential if the information is to be made compact and serviceable in the case of offerings not subject to the requirements of the Securities Act. For the security dealer or investment banker to undertake the job of simplification, condensation and summary involves a risk of liability of real concern. As has been stated, section I2 of the Securities Act creates a civil liability on those who sell a security by a misleading prospectus or other communication, written or oral, and places the burden upon the seller to establish that he had not known, and in the exercise of reasonable care could not have known, of the misleading character of the communication. Moreover, the civil liability created by section 17 (a) of the Securities Act and section $10(b)$ of the Securities Exchange Act as implemented by Rule rob $-^{41}$ may not permit a defense of lack of knowledge or reasonable care. ${ }^{42}$ The civil liability risks of an attempt by a security dealer himself to condense or summarize filed material information concerning earnings and other aspects of the reports of an issuer would seem to be sustantial in the absence of a clear rule promulgated by the Commission granting absolution from civil liability for a summarization or condensation fairly made in good faith by the disseminator of the filed information. Existence of such a rule and the brokerdealer's reliance upon it would absolve him from civil liability pursuant to section 19(a) of the Securities Act and section 23(a) of the Securities Exchange Act.

In the absence of a clear rule of absolution, the broker-dealer held liable for the dissemination of information contained in filed reports which is in fact misleading may have no effective remedy against the company or its controlling persons who were responsible for the filing of such information with the Commission. Section I7(a) of the Securities Act and section Io(b) of the Securities Exchange Act and its implementing Rule Iob-5 apply only when misleading statements are made in the "offer or sale" of a security. In many of the transactions in which broker-dealers might have to disseminate information to their customers, it would be impossible to hold that the issuer or its controlling persons in any way engaged in the offer or sale of a security. Moreover, it is not at all clear that even if the issuer or its controlling persons were offering or selling a security that the broker-dealer (who has not purchased any security) would have a right under either of these sections against

${ }^{12}$ Sec. $17(a)$ of the Securities Act, generally speaking, makes it unlawful for any person to scll a security by misleading statements or omissions or by deceptive, fraudulent or manipulative devices or practices. Sec. Io(b) of the Securities Exchange Act and Rule rob-5 make it unlawful in connection with a purchase or sale of a security to engage in such practices. For a discussion of the civil liabilities created by these sections and Rule Iob-5, see 3 Louis Loss, Securities Regulation I763-97 (2d ed. $196 \mathrm{I}$ ).

${ }^{6} 3$ Loss, op. cit. supra note $4 \mathrm{x}, 2 \mathrm{t} 1765$, I779. 
the issuer or its controlling persons. The direct remedy available to those persons injured by false statements made in any reports or documents filed under the Securities Exchange Act is contained in section 18 of the act. However, recovery requires proof by the injured person that he relied upon the false statements (which presumably would not be too difficult) and, more important, that such false statements affected the price at which the security was purchased or sold (often an impossible task of proof). Even if this heavy burden of proof is met, recovery may still be defeated if the person sued can prove he acted in good faith and had no knowledge that the statement relied on was false. ${ }^{43}$

\section{Who Shall Be Required to Disseminate Informatton}

The Securities Act, as has been stated, requires a written prospectus to reach the investor and places this obligation on the issuer, underwriters, and dealers who are in the chain of distribution, as long as they have unsold allotments of the security. This obligation, in effect, is placed upon all other dealers selling such securities for a period of forty days after the effective date of the registration statement. ${ }^{44}$ On the other hand, the Securities Exchange Act contains no express obligation upon the part of anyone to bring the information concerning the corporation and its "insiders" which must be filed with the Commission to the attention of investors or even of stockholders. ${ }^{45}$

The rationale for the differences in the requirements of the two acts derives essentially from the nature of "distribution" as against "trading" in securities. The Securities Act offering involves a "distribution," i.e., the sale of a large block of securities emanating from the issuer or its controlling persons and effectuated usually through the organized channels and mechanics of a securities offering-a con-

\footnotetext{
${ }^{13}$ For a discussion of the infirmities of the civil remedy afforded by $\$ 18$ of the Securities Exchange Act, see 3 Loss, op. cit. supra note 41 , at I75I-54.

${ }^{11}$ Securities Act $\$ 4(\mathrm{I})$. The Commission's proposed legislation discussed in note 25 supra, would, if enacted, empower it to shorten the forty-day period or to increase the period to a maximum of ninety days in the case of more speculative issues. The Special Study's short-form integration regulation includes a suggestion in cases approved for short-form prospectuses that the forty-day dealer use period be eliminated. Implicit in this suggestion is that the short-form prospectus would be made available only in the case of seasoned companies. However, many companies listed on national securities exchanges and many over-the-counter companies which would become reporting companies if the Commission's proposed legislation is passed are far from high grade on any basis of security analysis. By and large, if mere reporting is to be the criterion for short-form prospectus treatment, the forty-day period should be maintained.

"The national securities exchanges require listed companies to transmit an annual report including certified financial statements to shareholders. See N.Y. Stock Exchange Codipany Manval § 4 A. For example, the NYSE requires the annual report to be submitted to shareholders at least fifteen days prior to the stockholders' annual meeting, but not less than three months after the close of the company's fiscal year. The Commission has recently adopted an amendment to its proxy rules requiring proxy statements to be accompanied or preceded by an annual report containing financial statements certified by independent public accountants in form and content as filed in the company's annual report to the Commission on Form 10-K. Rule 143-3 of the General Rules and Regulations under the Securities Exchange Act of I934. I7 C.F.R. $\$ 240.142-3$ (Cum. Supp. I963).
} 
tractual linking together of underwriters and dealers who in some cases assume substantial pecuniary risks and in all cases are compensated at rates higher than those usually obtainable in transactions involving purchases and sales of securities among investors and broker-dealers. In these "distributions," therefore, incentives for the rapid and aggressive selling of the securities exist. ${ }^{48}$ There is, therefore, need of some type of apparatus to overcome the blandishments of salesmen and others motivated by the prospect of higher than usual gain or reward. The physical dissemination of material information in crystallized, coherent form is essential to enable investors in such circumstances not only to form a judgment as to the objective merits of the security, but also to appraise and evaluate the optimistic predictions, promises and forecasts which may be made to them by salesmen. In short, the essential fact situation with which the Securities Act deals is the presence of an inventory of securities to be offered rapidly to the public with the prospect of comparatively high rewards to underwriters and dealers.

This same fact situation, however, does not exist in the case of trading in outstanding securities among investors and dealers. The Securities Exchange Act is premised upon the belief that brokers in listed securities who, under the rules of the exchanges, receive like commissions for identical dollar amounts of investments in listed securities, are unlikely to over-pressure investors to purchase a particular security. The information under the act is thus intended to be available essentially for the information of brokers who are capable of digesting it, analyzing it, collating it, and forming a judgment which is transmitted to investors without undue pecuniary bias. To be sure, investors may be solicited to purchase listed securities, but in the absence of the pecuniary drive of the ownership by the broker of an inventory of securities which may create peculiar incentives to dispose of the particular security, the solicitation is presumably based, and indeed legally required to be based, upon an honest and unbiased appraisal.

These essential differences between trading and distribution suggest a reasonable classification of those who should or should not be compelled to disseminate information to investors in the form of a prospectus or circular in the case of offerings not subject to registration under the Securities Act. In short, those who

\footnotetext{
${ }^{40}$ See the Special Study, pt. I, at $48 \mathrm{r}-82$ for a discussion of the distinction between "distribution" and "trading." Distributions not requiring registration under the Securities Act may be made of listed as well as unlisted securities. Although many unregistered distributions may be made "rcgular way" on an exchange, the exchanges have developed techniques, such as the "exchange distribution" and the "special offering plan," to dispose of large blocks of securities quickly using the facilities of the exchange but outside the auction market. Both the exchange distribution and special offering plan technique are characterized by the payment to salesmen of a higher rate of compensation than they would receive with respect to normal trading transactions. See Special Stzdy, pt. I, at 560-64, for a description of the types of unregistered distributions. There is no reason why these types of unregistered distribution of listed securities should not be subjected to any requirement for information dissemination which the Commission may evolve in connection with unregistered distributions. Sales of large blocks of listed shares, however, "regular way". which do not require registration' under the Securities Act, should not be within such a rule so long as the distribution is not accompanied by the use of devices to stimulate sales.
} 
offer an inventory of securities substantial in dollar amount to the total outstanding securities of the same class, on an organized basis to the public, whether directly themselves through their own salesmen or through an independent dealer group, should be required to furnish information directly in the form of a prospectus or brochure to those who are offered the security. This general rule would free from the requirements of physical delivery of information to investors, security dealers who are merely recommending an offering of securities to investors which they do not own in quantity and which they have concluded are of investment merit based on their own examination of the information afforded by the Securities Exchange Act. Similarly, the National Association of Securities Dealers' "fair mark-up" interpretation of its rules of fair practice imposes limitations on the pecuniary gain to over-the-counter dealers in such transactions. ${ }^{47}$ The situation is thus somewhat analogous to the standard commissions which brokers obtain on the purchase and sale of listed securities. On the other hand, brokers and dealers participating in a distribution of an inventory of securities, listed or unlisted, on commission or other remunerative bases higher than the usual commissions (or who have a large, unrealized profit upon an inventory offered over the counter on even a fair mark-up basis) should be obligated to furnish information to investors in physical form prior to their actual purchase of the security.

The broker-dealers who are capable of assembling for their own account, or offering on behalf of others, large inventories of securities and distributing them to the public are usually the firms with substantial amounts of capital who are quite capable of preparing information for circularization to investors. Indeed, there seems to be a recent tendency for investment bankers or security dealers offering substantial inventories of securities, listed or unlisted, which involve commissions or pecuniary gains substantially higher than those obtainable in ordinary trading transaction, to prepare and distribute written information to investors concerning the issues notwithstanding the possible danger of civil liabilities to which reference has already been made. Moreover, the unfolding development of the content of the phrase "manipulative, deceptive and fraudulent practices" as used in the Securities Exchange $\mathrm{Act}^{48}$ in the Commission's opinions in broker-dealer disciplinary proceedings under the Securities Exchange Act indicates a strong tendency to pronounce

\footnotetext{
${ }^{17}$ See National Association of Securities Dealers (NASD) Manual Gi-6 (r964). The Manual states that as a general rule "it shall be deemed inconsistent with just and equitable principles of trade for a member to enter into any transaction with a customer in any security at any price not reasonably related to the current market price of the security or to charge a commission which is not reasonable." Although the NASD's policy acknowledges that reasonableness is a function of many factors including the price, availability and market for the security, in general practice a mark-up of five per cent of the current offering price in the over-the-counter market (assuming there is a valid and independent market) in most cases is deemed reasonable. The NASD's fair mark-up policy, however, does not apply to the sale of securities where a prospectus or offering circular is required to be delivered and the securities are sold at the specified offering price.

${ }^{4}$ Sec Securities Exchange Act $\$ \S \mathrm{ro}(\mathrm{b}), \mathrm{I}_{5}(\mathrm{c})(\mathrm{I})$ and $(2)$ and the rules promulgated by the Commission pursuant to the authority of these sections.
} 
the failure to deliver such information in such cases within the prohibition of this phrase.

The Commission has increasingly taken the position that recommendations of securities being distributed in an organized manner by dealers and salesmen must be backed by information to substantiate the reasonableness of the security analysis or predictions made to the public. The Commission in fact has stated in the case of distributions of lesser known securities that it is almost a positive obligation for dealers making distributions of inventories of such securities to supply investors with the material facts concerning the issuer. Thus, it has stated:

A broker-dealer undertaking the sale of a block of securities ... has the further problem of avoiding conduct which will violate the anti-fraud provisions of the federal securities laws. In making such a distribution, he will probably find it necessary, or at least desirable, to recommend purchase of the security by his customers. The Commission has, however, repeatedly held that it is a violation of the anti-fraud provisions for a brokerdealer to recommend a security unless there is an adequate and reasonable basis for the recommendations, and, further that such recommendations should not be made without dis. closure of facts known or reasonably ascertainable, bearing upon the justification for the recommendation. As indicated, the making of recommendations for the purchase of a security implies that the dealer has a reasonable basis for such recommendations which, in turn, requires that, as a pre-requisite, he shall have made a reasonable investigation. In addition, if such a dealer lacks essential information about the issuer, such as knowledgc of its financial condition, he must disclose this lack of knowledge and caution customers as to the risk involved in purchasing the securities without it. . . 49

It is true that these statements by the Commission were made with respect to distributions of so-called "obscure" securities. Nevertheless, the Commission's conclusions would seem to be of universal applicability. Certainly broker-dealers recommending any security would do well to be fortified with current information concerning the company which reasonably supports their recommendation. Even more protection from the standpoint of avoidance of disciplinary proceedings can be obtained by the delivery of such information to investors..$^{50}$

If information is to be physically delivered to investors in connection with a distribution not subject to the Securities Act registration requirements, reasons of

\footnotetext{
${ }^{10}$ See SEC Securities Act Release No. 4445 (Feb. 2, 1962). (Footnotes omitted; emphasis added.) In' the Matter of Alexander Reid \& Co., Inc., SEC Securities Exchange Act Release No. 6727 (Feb. 8, 1962) the Commission stated: "A broker-dealer in his dealings with customers implicdly represents that his opinions and predictions respecting a stock which he had undertaken to recommend are responsibly made on the basis of actual knowledge and careful consideration. Without such basis the opinion and predictions are fraudulent ...."

${ }^{50}$ The New York Stock Exchange in its NYSE Guide, para. 2474A10, states: "(I) RecommendationsIn recommending the purchase, sale or switch of specific securities, supporting information should be provided or offered."

In the Matter of D. F. Bernheimer \& Co., Inc., SEC Securities Exchange Act Release No. 7000 (Jan. 23, 1963), the Commission stated: "We have repeatedly held that it is inconsistent with principles of fair dealing and violative of the securities laws for a broker or dealer to induce purchases of securities by means of representations unsupported by a reasonable factual basis and without disclosure of known or reasonably available information necessary to provide the investor with a fair picture of the sccurity being offered." (Emphasis added.)
} 
practicality and expediency would compel some finite rule by the Commission defining the "distributions" which should be accompanied by such delivery. ${ }^{51}$ Since the obtaining and crystallization of information in an offering circular may involve a degree of expense, requirements for physical delivery of information should be restricted to distributions which can support such expense.

As a tentative suggestion, for example, an offering involving solicitation by salesmen, with compensation to them for effecting sales higher than that paid in trading transactions involving similar securities or resales of inventories, where there is a substantial profit to be obtained on the basis of the cost of the inventory, should be conditioned upon the physical delivery of information to investors, if the offering involves or is one of a known series of contemplated offerings which will involve either more than five per cent of the outstanding shares of the issuer, or a total offering price of $\$ 300,000$ or more. The $\$ 300,000$ figure is arbitrary, but it is a figure in current use by the Commission to define an offering unregistered under the Securities Act for which market stabilizing operations by the offerors in aid of the distribution must be reported to the Commission. ${ }^{52}$ Thus the proposed rule for physical distribution of information will have a nexus with existing and known practice in connection with these types of offerings. Similarly, a finite definition of the "distributions" which would be subject to a requirement for the physical delivery of information to investors should also be synchronized with any new definition of a "particular distribution" under Rule rob-6 of the Securities Exchange Act, which may ultimately be evolved as a result of discussions between the Commission and the securities industry. Rule rob-6, generally speaking, prohibits issuers, underwriters and dealers from bidding for or purchasing securities in the open market while securities of the issuer of the same class are the subject of a "particular distribution" to the public. The most vexing problem in connection with this rule from the industry standpoint has been its failure to define the word "distribution." The Special Study recommends that the rule be amended to define "distribution"

${ }^{51}$ Sections ${ }^{2}$ (c)(I) and (2) of the Securities Exchange Act confer upon the Commission rulemaking power to define deceptive, manipulative and fraudulent devices and practices. Presumably, a rule could be enacted pursuant to this section to codify the trend of Commission decisions illustrated by the Bernheimer case, supra note 50 , and the cases cited by the Commission in that case. See also Comment, Current Problems in Securities Regulation, 62 Mrcr. L. REv. 680, 730-50 (1964).

${ }^{52}$ See Rule Iya-2(a) of the General Rules and Regulations under the Securities Exchange Act of 1934, 17 C.F.R. $\$ 240.172-2$ (a) (Cum. Supp. 1963). The $\$ 300,000$ figure also corresponds to the maximum public offering which the Commission may exempt from the registration requirements of the Securities Act of 1933. Securities Act $\$ 3(\mathrm{~b})$. See also Rule 254 of the General Rules and Regulations under the Securities Act of 1933, I7 C.F.R. $\$ 230.254$ (Cum. Supp. 1963). Rule 256 of the General Rules and Regulations under the Securities Act of 1933, I7 C.F.R. $\$ 230.256$ (Cum. Supp. 1963) requires as a condition to exemption from the usual requirement of the Securities Act the filing with the Commission of an "offering circular" which must be given to purchasers of the securities and which contains all of the information in the categories of disclosure set forth in the text but does not require financial statements to be certified by independent public accountants. The use of an offering circular in offerings of less than $\$ 300,000$ has proved to be economically feasible.

${ }^{8}$ See Whitney, Rule rob-6, The Special Study's Rediscovered Rule, 62 MIcr. L. REv. 567 (I964); see also Special Study, pt. I, at 568 . 
for the purpose of the rule to relate to offerings of $\$ 300,000$ or more. ${ }^{64}$ The desirability of a precise definition of "distribution" is clear; it would seem equally desirable to enlarge this rule to include a requirement for the dissemination of information with respect to the distributions to be covered by the rule as ultimately amended. The combination will facilitate a greater accomplishment of the purpose of Rule Iob-6 to prevent fraud.

\section{III}

\section{Scope of Information to Be Disseminated}

Consideration must now be given to the minimum areas of information which should be disseminated to investors, both in the case of issues registered under the Securities Act and in the case of securities of companies subject to the reporting requirements of the Securities Exchange Act as it now exists and as proposed to be amended by the legislation sponsored by the Commission.

Both the Securities Act and the Securities Exchange Act are essentially disclosure statutes. They are postulated on the premise that purchasing and selling securities is a rational process which can be aided by current material information concerning the company and its financial and earnings prospects. However, the degree of disclosure to be furnished investors depends upon the objective sought by the disclosure. Thus disclosure can be based simply on the notion that the information supplied should be sufficient to prevent a gross fraud and to enable an investor to appraise properly the more extravagant blandishments of salesmen. On the other hand, if the objective of disclosure is to enable a careful comparative analysis of the security against securities of other companies in the same industry, or securities of companies of other industries, a greater amount of information must be supplied.

Historically, in England, the objective of prevention of fraud has been the paramount consideration in framing disclosure requirements. The Companies Act of 1948 and its predecessors have not required essential material for security analysis such as "turn-over" information, i.e., information as to gross sales and cost of sales in income accounts. Nor are details of the issuer's business by divisions and percentages of sales required to be disclosed. ${ }^{55}$ The Commission, on the other hand,

su Special Study, pt. I, at 570 .

"The Jenkins Report recommends that "turnover" figures be included in each of the five-ycar's earning statements required for prospectuses by the Fourth Schedule of the Companics Act. Sec JENkins RePoRT 19 243, 393. The Jenkins Report also found that in many cases publicly-owned companies did not comply with the Companies Act requirement that the annual report to shareholders include, among other things, "the main activities of the company and its subsidiaries during the fiscal ycar" and "any major change in these activities during the year."

Although the Companies Act does not require the prospectus to contain anything more than a description of the general nature of the business done by the company, the London Stock Exchange does require information as to the relative importance of the divisions of its business wherc a company carries on "two or more activities which are material having regard to profits and losses, assets employed, or other factors." Appendix 36 of the Rules of the London Stock Exchange at 203 (1962).

The Jenkins' Report recommends that the Companies Act be amended to require prospectuses to meet the same standards as those set forth by the London Stock Exchange Rule. JENkins Report I252(e). 
within the confines of its permissible authority under the Securities Act, has gone further and sought to obtain information which at least would form the basis for a reasonable securities analysis. It has not required all the information necessary to an analysis in depth of the value of a particular company's securities. For example, little information concerning labor relations or labor contracts is required to be included in registration statements under the Securities Act nor is it possible to determine relative costs of labor in the total operating expenses of the company. Comparative profit margins of the issuer and the industry in general or other industries is not commonly disclosed. Nevertheless, the Commission by its accounting requirements which enable gross profit margins to be determined and its requirement for disclosure of comparative conditions and the place of the company in its own industry provides some material for comparative analysis. ${ }^{\overline{0}}{ }^{6}$

Both the Securities Act and the Securities Exchange Act define in detail the areas of information to be obtained in registration statements for the sale of securities to the public or for listing on national securities exchanges. The Securities Exchange Act is more rigid than the Securities Act in that the discretion of the Commission to obtain additional or different information is less flexible than its authority under the Securities Act. The latter act empowers the Commission to expand the statutory categories of required information if it finds it necessary in the public interest or for the protection of investors. However, it may not permit the omission of any material required by law unless it is able to find that disclosure fully adequate for the protection of investors is otherwise included in the registration statement. ${ }^{57}$

The Commission's powers, however, in respect of the prospectus as distinguished from the registration statement are more ample. It may permit the omission from the prospectus of information required to be included in the registration statement if it finds that such omitted information is not necessary or appropriate in the public interest or for the protection of investors. ${ }^{58}$

The Securities Act in its Schedule A sets forth thirty-two paragraphs containing areas of information to be included in a registration statement. The Securities Exchange Act, although more concise in its requirements, ${ }^{59}$ presently permits the Commission to obtain basically the same information it could obtain in a registration statement under the Securities Act with the exception of its inability to obtain information concerning material contracts of the company whether or not made in

Thus, if the Jenkins Report's recommendations are adopted, the Companies Act requirements will move very substantially toward the concept of a prospectus which requires adequate information for a securities analysis. This movement is to be contrasted with the Special Study's recommendation of a short-form prospectus.

${ }_{66}^{6}$ For a discussion of a rationale for determining areas of information necessary for a securities analysis, see Heller, Disclosure Requirements Under Federal Securities Regulation, I6 Bus. Law. 300 $(\mathrm{rg} 6 \mathrm{r})$.

67 Securities Act $\$ 7$.

${ }^{28}$ Securities Act $\$$ Io(a) (4).

${ }^{50}$ Securities Exchange Act $\$$ I2(b). 
the regular course of its business. As already indicated, this deficiency will be corrected if the legislation now pending before the Congress is adopted.

The information required by both acts to be included in registration statements may be broadly divided into five categories:

Category $A$ includes information concerning the company's organization and a description of its business and operating properties.

Category $B$ includes financial statements, that is, a balance sheet and income accounts for the three preceding fiscal years certified by independent public accountants.

Category $C$ includes a description of securities being offered as well as capitalization of the company and the effect of the rights of the securities being offered upon the rights of the outstanding securities as well as the effect upon the securities being offered of the rights of the outstanding securities and a description of the proposed use of the proceeds of the offering.

Category $D$ includes the names and addresses of the directors, officers and controlling persons of the issuer, their existing and proposed remuneration and a description of their past and contemplated transactions with the issuer and its subsidiaries.

Category $\mathrm{E}$ includes the names and addresses of the underwriters, a description of the terms of the underwriting agreement and the amount of the underwriting commissions and other things of value to be received by the underwriters.

Historically, all of these categories of information (with some exceptions which will be discussed later) have been required to be included in registration statements and prospectuses under the Securities Act. In its prospectus requirements the Commission generally has heeded Speaker Rayburn's oft-quoted comment that securities are "intricate merchandise," and that this fact should be impressed upon investors by a requirement that the prospectus contain virtually all of the revelations in the registration statement. In Mr. Rayburn's report on behalf of the House Committee on Interstate and Foreign Commerce with respect to the Securities Act, he stated:

The purpose of these sections is to secure for potential buyers the means of understanding the intricacies of the transaction into which they are invited. The full revelations required in the filed "registration statement" should not be lost in the actual selling process. This requirement will undoubtedly limit the selling arguments hitherto employed. That is its purpose. But even in respect of certain types of listed issues, reputable stock exchanges have already, on their own initiative, recognized the danger of abbreviated selling literature and insisted upon supervising the selling of literature distributed in connection with such issues, to make certain that such literature includes the same information concerning the issue required in a formal circular filed with and approved by such exchanges. Any objection that the compulsory incorporation in selling literature and sales argument of substantially all information concerning the issue will frighten the buyer with the intricacy of the transaction, states one of the best arguments for the provision. The rank and file of securities buyers who have hitherto bought blindly should be made aware that securities are intricate merchandise. ${ }^{00}$

\footnotetext{
${ }^{60}$ H.R. Rep. No. 85, 73d Cong., Ist Sess. 8 (r933).
} 
If the Commission is to depart in its prospectus requirements from the principles set forth by Speaker Rayburn, it can only do so if it finds that the public interest and the protection of investors make such departure desirable. ${ }^{61}$

The traditional argument is that prospectuses are not generally read because they are too long and because the information they contain is too complex to be understood by the average investor. This argument exaggerates the problem. In the one instance in which the Special Study investigated the reactions of investors to prospectuses, it was discovered that a substantial number of investors read prospectuses and spend considerable time in doing so-albeit that there was some question about the degree to which these investors understood what they were reading. ${ }^{62}$ According to a recent study of individual stock ownership, seventy-five per cent of individual shareholders are either engaged in professional or managerial occupations. ${ }^{63}$ This same study also indicates that individual stockholders in the lower economic groups tend to avoid speculative issues and to concentrate their investments in stocks of telephone and communication companies, electric and gas utilities, and investment companies. The middle and upper income groups contain the persons most willing to invest in speculative securities. Thus, the ability to read and to understand prospectuses does not necessarily appear to be beyond the capabilities of the average investor. In addition, the Commission, itself, has made great strides in reducing the length of prospectuses without eliminating any vital information contained in the categories of disclosure set forth above.

The determination of the categories of information to be included in the prospectus depends primarily upon the degree to which the Commission deems it important to provide facts required for security analysis as distinguished from information solely needed to offset the predictions and exaggerations of salesmen. Neither the Securities Act nor the Securities Exchange Act states which of the two objectives is to be achieved. However, as is indicated by the definition of "material" in Rule 405 of the General Rules and Regulations under the Securities Act, ${ }^{64}$ the Commission has sought attainment of the first objective-at least in connection with the distribution of securities registrable under the Securities Act.

From the viewpoint of economic theory, investment in securities is basically a placing of capital with a view to as large a return as possible consistent with the

${ }^{01}$ Securities Act $\$$ Io(a)(4).

${ }^{02}$ At the request of the Commission, the Securities Research Unit of the Wharton School of Finance and Commerce, University of Pennsylvania, conducted a "Survey of Mutual Fund Investors." The Survey developed the fact that "the average time devoted to reading the prospectus was a little over one hour for regular purchases and a little less than an hour and a half for those who bought contractual plans." See Special Study, pt. 4, at 343 .

${ }^{63}$ See Crockett \& Friend, Characteristics of Stock Ownership, in American Statistical Associatron, 1963 Proceedings of the Business and Economic Statistics Section I46 ( Ig6 $_{3}$ ).

of 17 C.F.R. $\$ 240.405$ (I949). 'The rule states that 'the . . . term 'material,' when used to qualify a requirement for the furnishing of information as to any subject, limits the information required to those matters as to which an average prudent investor ought reasonably to be informed before purchasing the security registered." 
risks involved in the enterprise selected for investment. ${ }^{05}$ Given this economic premise, intelligent analysis of possible future returns on an investment will require, as a minimum, disclosure of information within Categories $\mathrm{A}, \mathrm{B}$ and $\mathrm{C}$ set forth above. Only to a lesser extent would information in Categories $D$ and $E$ be of importance in determining the economics of an investment. ${ }^{66}$ Generally speaking, it is the first three categories of information which have been stressed by the Commission in its prospectus requirements. Indeed, the Commission has gone beyond the statutory requirements as to statements of earnings. It requires a summary of earnings of at least five years as against the statutory requirement for a three-year statement of earnings. And the Commission has in its forms substantially increased disclosure requirements as to the history, development and characteristics of an issuer's business beyond the mere "statement of the general character of the business actually transacted or to be transacted by the issuer" which Schedule $A$ requires. Information is presently required in prospectuses concerning the different kinds of services or products manufactured by the issuer and their contributions to gross sales. In addition, information is required as to the general competitive conditions in the industry in which the company and its subsidiaries are engaged and the position of the company and each of its important divisions in the industry of which they are a part. In essence, what the Commission is requiring presently is a description of the business of the company and the development of such business during the five-year period of the summary of earnings included in the prospectus, with a view to showing primarily the risk factors in the business as indicated by its development and the course of its sales and earnings (frequently by divisions of its business) during such five-year period.

Generally speaking, in the case of only one type of security offered to the general public has the Commission varied its registration and prospectus requirements under the Securities Act from the principles set forth by Speaker Rayburn. In 1954 the Commission promulgated Form S-9 for registration under the Securities Act of non-convertible, fixed interest, non-subordinated debt securities of domestic issuers which have been engaged in substantially the same general business for at least the last ten years preceding the filing of the registration statement. The issuer is required to have a very substantial degree of interest coverage both before and after the issuance of the proposed securities and must be a company which has been filing reports with the Commission pursuant to the requirements of the Securi-

\footnotetext{
${ }^{05}$ See Heller, Disclosure Requirements Under Federal Securities Regulation, 16 Bus. LAw. 300 (I96I), for an claboration of this thesis.

${ }^{88}$ Although information on the remuneration of officers and directors and their material transactions with the company may be of some significance in making an investment judgment concerning a security, information as to the names and participations of underwriters is primarily important to disclose those who will be liable as underwriters under $\$ \S \mathrm{II}$ and $\mathrm{I}_{2}$ of the Sccuritics Act. Information as to underwriting commissions is of little analytical significance unless such commissions are so gross in character as to warrant action by disciplinary authorities. The prime function of the investor is to weigh the price which he is asked to pay for the security offered to him against the earnings prospects of the security revealed by the information in Categories $A, B$, and $C$.
} 
ties Exchange Act. The registration form requires information only as to selling commissions, use of proceeds, summary of earnings and surplus, a description of the securities being registered, and balance sheets and other financial schedules. This is all the material required to be incluaed in the prospectus. The names of the underwriters and information concerning the expenses of issuance and distribution is required to be included only in the registration statement.

Neither the prospectus nor the registration statement expressly provide for a disclosure of the business of the company of the character generally required in the general forms of registration statements promulgated by the Commission. The Special Study's "short-form" proposal would also omit this requirement. However, the item in Form S-9 requiring a summary of earnings contains a statement requiring the prospectus "whenever necessary, [to] reflect information or explanations of material significance to investors in appraising the results shown" in the summary of earnings. In addition, the same item also contains a provision requiring a statement of the products or services which constitute the principal source of sales or revenues, and a statement of gross property additions and retirements for the period covered by the summary of earnings. In the case of an extractive enterprise, appropriate information as to reserves must be set forth.

As a consequence of these requirements the financial bar invariably inserts in prospectuses a description of the business in the same style and content as would be required under the Commission's general forms of registration. ${ }^{67}$ In sum, although Form S-9 and its prospectus requirements are theoretically "short-form," in actual practice prospectuses issued in compliance with the form contain all of the information which would be required for registration of an equity security under the Securities Act except the information in Categories D and E (other than commissions).

Form S-9 should not be regarded as a model for short-form prospectuses in general. This form relates only to senior securities with high interest coverages issued by companies, primarily utility-operating companies, in which self-dealing by directors and officers is usually non-existent because of the extensive regulations of such companies by state authorities. In such companies remuneration to officers and directors is of little importance in the light of the high-interest coverages required as a condition to the use of the form. Moreover, the form deals with securities sold almost entirely to institutional investors who are quite capable of ascertaining and examining the information on file with the Commission with respect to other categories of information not included in the registration statement. ${ }^{68}$

o7 The Form S.9 registration statement of Sprague Electric Company, Registration No. 2-21634 (1963), is typical. Form S-9 has been used predominantly by utility and telephone companies. In this type of company the information in Categories $\mathrm{D}$ and $\mathrm{E}$ is of little importance, since the companies are regulated and stock options and other incentive compensation and profit-sharing plans are comparatively rare or, in any event, must be submitted for approval to a state regulatory body. Moreover, the securities of these companies are increasingly sold by way of competitive bidding and underwriting commissions tend to be extremely small.

${ }^{68}$ In addition to Form S-9 the Commission has promulgated another short-form registration 
The Special Study's case for short-form registration statements and prospectuses in the case of reporting companies rests in large part on the notion that securities of these companies are traded on exchanges and over-the-counter daily on the basis of the filed information, without any formal delivery of written information to investors. Because of this fact the Special Study argues that justification can be found for shortening informal requirements when securities emanate from the company or its controlling persons and are sold in large blocks to investors in an organized campaign of offering.

The Special Study's proposition, however, ignores the fact that issuance of new securities by a company in effect represents a reconstitution and a renewal of its business. And sales by controlling shareholders in themselves suggest a need for re-examination and current information concerning the enterprise whose securities the controlling persons propose to sell to the public. ${ }^{80}$ In addition, as already in-

statement known as Form S-8. This form is restricted solely to the registration of employec stock purchase plans in which substantial contributions are made by the employer in cash, securitics, or other substantial benefits, and to restricted stock option plans as defined in $\$ 42 \mathrm{I}(\mathrm{d})$ of the Internal Revenue Code of $x 954$. The only information required by the form concerns the plan and the securities subject to the plan, and the eligibility and extent of participation by employees. Some information about the stock being issued is also required; however, such information is much less than that requircd on Form S-r. Form S-8 requires a summary of earnings of the company for the last five fiscal ycars and a statement of the range of market prices of the security being offered for the same period. It also requires a description of any bankruptcy, receivership or any material reorganization, capital rcadjustment, or other significant fact concerning the company or any significant subsidiary otherwise than in the ordinary course of business. The description of the stock being registered is also requircd. Finally, certified financial statements of the company for its last fiscal year must be included. The use of Form S-8 is restricted to companies reporting to the Commission pursuant to the requirements of $\$ \$ 13$ or $I_{5}$ (d) of the Securities Exchange Act and all the information in the registration statement must be included in the prospectus.

The short-form character of the information required in Form S-8 is undoubtedly justified by the fact that since the employer must make a substantial contribution to the plan, the employees are obtaining a bargain purchase of the securities offered or by the fact that the employees will receive options which they can exercise or not exercise, depending upon the profit they can realize upon exercise. Significantly, however, the form provides that if, in the case of stock option plans, there is to be a rcoffering of stock acquired pursuant to options by persons who would be underwriters under the statute (for example, if the stock were acquired with a view to distribution), the form must be amended prior to any public offering to provide all the information required by Form S-I unless the stock is to be offered on a national securities exchange. By not requiring an amendment, in the case of "regular way" offerings on an cxchange, the Commission indicates clearly its belief that "regular way" trading at ordinary commissions would not involve aggressive selling of the character which would make necessary the presentation of information directly to investors. On the other hand, however, it is difficult to distinguish sales by those who exercise options and who are underwriters from sales by controlling persons which must be registered cven if "regular way" sales are all that is contemplated. Because of the unique and specific character of Form S.8, it would not seem to provide a model for a general form of short-form prospectus.

${ }^{\circ}$ The Special Study would require a prospectus disclosure of the reasons for the public offering of their own securities by controlling shareholders. No such requirement appears in the Securities Act and the present practice of the Commission is to obtain such reasons as supplemental information for the use of the Commission's staff. The staff further requires the supplemental statement of reasons for the proposed sale to include a representation that the selling stockholders are familiar with the registration statement and also requires that there be set forth any material adverse information known to the selling security holder with regard to current and prospective operation of the registering company not disclosed in the prospectus (or a negative representation to such effect, if applicable). Sce Guides for Preparation and Filing of Registration Statements \$27, SEC Securities Act Release No, 4666, Fcb. 7, 1964. The prevailing practice seems more desirable and practicable than the Special Study's proposed 
dicated, the absence of a strong bias which is attendant upon ordinary trading in outstanding securities by brokers and dealers is not present when a large block of securities emanating from the company or its controlling persons is being distributed on an organized basis to investors. In such circumstances no clear reason can be seen for depriving the investor of the information which is presently required to be included in registration statements and prospectuses.

The Special Study's proposal would require information in all categories which have been set forth above except a description of the business in terms of its risks, and the salaries and other remuneration of officers, directors and controlling stockholders, option plans and insider transactions. Under the Special Study's proposal, these categories of information presumably would be left for the underwriters and dealers to impart to investors. However, examination of current registration statements and prospectuses makes it clear that these categories of information do not in most cases occupy a great portion of the prospectus and that the omission of this information will not greatly shorten a prospectus. Since both the Congress and the Commission have normally taken the view that this information is essential, particularly in the sale of equity securities to investors, it is difficult to see how the "shortening" of the form of registration statement and prospectus by the omission of these items of information contributes anything of value to the administration of the securities laws and the protection of investors. Indeed, if disclosure of this information requires a large amount of space, the likelihood is that such information is very material. Stock option and profit-sharing plans which entail the possibility of a substantial dilution of the equity of investors should certainly be required to be disclosed together with their dilution potential. Only in cases where earnings are so substantial that option plans and profit-sharing plans can have little dilution effect can their omission be justified.

However, in cases of an unregistered distribution concerning which, as outlined above, it is suggested that a Commission rule should be promulgated requiring information concerning the issuer and its securities to be physically conveyed to investors, reasons of expediency and economy suggest a somewhat different treatment. Certainly the indispensable information concerning the company's earnings, business (and the risks which may be inherent in the business), and a description of the rights of the securities offered in relation to the rights of all outstanding securities, must be supplied. Perhaps, however, information concerning remuneration, option and profit-sharing plans should not be required to be disclosed in cases of unregistered distributions if the issuer has net assets as disclosed by its latest balance sheet of at least $\$ 5,000,000$, has been engaged for the preceding three years in substantially the same business, and has earned at least $\$ 500,000$ for at least its last three fiscal years. Such an exemption would square with the standards of the Commission's

treatment. The Special Study's proposal will probably produce nothing more than statements concerning the necessity to pay estate taxes or the need to diversify the shareholders' assets. 
present rule for the use of "summary prospectuses." In the case of unregistered distributions of outstanding securities of issuers meeting these standards, the essential capitalization and business of the company remains unchanged and the effect of insider self-dealing, remuneration and profit-sharing plans have already been felt and reflected in the company's earnings. Information as to stock options, however, should be included, albeit briefly, in connection with the description of the company's capitalization if the stock subject to the options does not exceed five per cent of the outstanding shares. If the stock options relate to a greater amount of shares, information should be given as to the effects of the possible exercise of the option upon the outstanding shares. ${ }^{71}$

\section{Conclusion}

The general objective of the Special Study to require dissemination of information in the case of distributions which involve a solicitation of investors stimulated by extra compensation to salesmen or extraordinary profits to owners of the securities is to be commended. Indeed, this objective has been foreshadowed by Commission decisions in broker-dealer disciplinary proceedings. However, experience teaches that neither the industry nor the Commission particularly would or should tolerate short-form information which omits material and important categories of disclosure necessary in the light of the nature of the security and the purpose of the offering. The fact that information is on file concerning companies should not provide a reason for eliminating elements of information deemed vital by law for disclosure to investors. The essential goal of the securities laws-to place in the hands of investors offered securities a compendium of information necessary to enable them to make an adequate security analysis without the necessity of further inquiry or examination or information stored elsewhere-should not be sacrificed on the altar of short-form expediency.

\footnotetext{
${ }^{70}$ Rule $434 \mathrm{~A}$ of the General Rules and Regulations Under the Securities Act, I7 C.F.R. $\$ 230.434 \AA$ (Cum. Supp. 1963).

${ }^{32}$ For the type of disclosure presently required in the case of stock option plans which involve a high potential dilution of the equity of existing shares, see Guides for Preparation and Filing of Registration Statements I5, SEC Securities Act Release No. 4666, Feb. 7, I964.
} 